\title{
CONTROLES ESTRUTURAIS SOBRE A SEDIMENTAÇÃO DE FUNDO DE VALE NA BACIA DO RIACHO GRANDE/PB
}

\author{
STRUCTURAL CONTROL ON THE VALLEY \\ SEDIMENTATION IN THE RIACHO GRANDE \\ WATERSHED/PB
}

\author{
Ana Clara Magalhães de Barros ${ }^{1}$ \\ anaclarambarros@gmail.com \\ Antônio Carlos de Barros Corrêa ${ }^{2}$ \\ dbiase2001@terra.com.br \\ Bruno de Azevêdo Cavalcanti Tavares ${ }^{3}$ \\ brunoactavares@gmail.com
}

\begin{abstract} stream.

Keywords: Sedimentation, Structure, Valley Fill.

\footnotetext{
${ }^{1}$ Discente, Programa de Pós Graduação em Geografia, UFPE.

${ }^{2}$ Docente, Departamento de Ciências Geográficas, UFPE

${ }^{3}$ Docente, Departamento de Arqueologia, UFPE.
}

This paper analyzed the valley fill deposits of Riacho Grande watershed as a result of structural controls. These are responsible for depositional loci creation upon where alluvium-colluvium materials were deposited. The analysis were conducted by means of applying morphotectonic and morphometrical indicators such as relief and drainage lineaments and SL index. The results point to a geometrical disposition of the trunk stream following the NE-SW direction. The sedimentation processes overlaps erosion rates, forming floodplains along the trunk stream and its major tributaries. Sedimentation is controlled by transverse lithological dikes which block up and confine streams coming from the highlands. To the north of the study area, geological conditions are dominated by a sequence of structurally controlled ridges and valleys lacking hillslope colluvial coverage, with sediment accumulation confined to the riverbed. This sector presents morphometric anomalies associated to the presence of knickpoints along the the trunk 


\section{RESUMO}

Este trabalho buscou analisar os vales colmatados presentes na Bacia do Riacho Grande a partir dos controles estruturais responsáveis pela criação de loci deposicionais onde são estocados materiais colúvio-aluvionares. Para tanto, foram utilizados indicadores morfométricos como lineamentos de relevo e drenagem, relação declividade-extensão e indicadores morfotectônicos da bacia. A partir dos resultados obtidos podemos destacar que a disposição geométrica do riacho Grande obedece a uma direção preferencial para NE-SW. Os processos de sedimentação se sobrepõem à erosão, com formação de planícies de inundação ao longo do canal principal e seus principais tributários. Essa sedimentação é controlada pela presença de diques, que bloqueiam e confinam as drenagens oriundas dos setores de cimeira do maciço. Nos setores setentrionais, quebras de patamares se fazem presentes ao longo do curso do rio e estão associadas a anomalias de drenagem do principal curso fluvial dessa área, o riacho Grande.

Palavras-chave: Confinamento; Estruturas; Sedimentação.

\section{CONTEXTO DA PESQUISA}

A Geomorfologia historicamente tem trabalhado de forma sistêmica com a Geologia e a Geografia, e a perspectiva integrada adotada nesse trabalho recai na compreensão do encadeamento dos processos que atuam na elaboração e gênese do relevo. Seu uso na pesquisa geomorfológica vem representando uma ruptura na compreensão do papel temporal na modelagem dos eventos que formam a paisagem, devido à necessidade de estabelecer interações entre as escalas espaçotemporais, adequadas aos fenômenos estudados.

Os sistemas geomorfológicos são compreendidos como sistemas históricos, caracterizados por um grande número de variáveis independentes e que se retroalimentam em si mesmos, gerando um alto grau de complexidade e eventos formativos um tanto imprevisíveis. Para a compreensão da paisagem é mister 
trabalhar de forma integrada os elementos que a compõem, assim, o presente trabalho procurou trazer uma junção de dados geomorfológicos $\mathrm{x}$ geológicos, a fim de estabelecer os possíveis controles estruturais que atuam na sedimentação Quaternária nos setores elevados do Planalto da Borborema. A junção de dados dessas categorias também podem trazer luz a interpretações acerca da ocupação de sítios arqueológicos em áreas de baixios, várzeas e terraços fluviais (MÜTZENBERG, 2007). Esses setores são propícios para ocupação uma vez que possuem capacidade de retenção hídrica (água pluvial) e proximidade as fontes de água (eixos de drenagem).

A área pesquisada está situada na escarpa ocidental do Planalto da Borborema, mais precisamente no Maciço Sienítico da Serra da Baixa Verde e nos setores setentrionais adjacentes ao maciço. A Bacia do Riacho Grande possui suas cabeceiras na superfície de cimeira do planalto com cotas que ultrapassam os 1000 metros e segue seu curso para os setores dissecados ao norte do maciço até atingir cotas em torno dos 350 metros no Planalto Sertanejo. O curso do rio principal e seus tributários é marcado pela presença de sedimentação nas áreas mais elevadas da bacia e setores onde a sedimentação é escassa nas porções do baixo curso do rio. Assim, procurou-se estabelecer as causas da discrepância na disposição geométrica da sedimentação ao longo da bacia do Riacho Grande. Para tanto, buscou-se analisar os vales colmatados presentes na Bacia do Riacho Grande em função de controles estruturais responsáveis pela criação de loci deposicionais onde são estocados materiais colúvio-aluvionares, e os vales 
entalhados com sedimentação restrita no leito dos rios nos setores setentrionais da Bacia do Riacho Grande.

\section{ÁREA DE ESTUDO}

A Bacia do Riacho Grande tem suas cabeceiras nos setores de cimeira do maciço da Serra da Baixa Verde (Figura 1). O maciço em questão localiza-se em terrenos do embasamento cristalino da Província Estrutural Borborema, confinado pela Zona Transversal. O maciço é constituído de álcali-feldspato-sienito. Em termos estruturais, o maciço da Serra da Baixa Verde se encontra confinado na Zona Transversal e apresenta-se alongado no sentido NE-SW, em consonância com os trends regionais, como as Zonas de Cisalhamento sinistrais que cortam a Zona Transversal, sobretudo a Zona de Cisalhamento Serra Talhada (CORREA, 2001; CORREA et al, 2010; TAVARES, 2015).

As áreas ao norte adjacentes ao sienito está representada pela ocorrência de granitos e granodioritos do tipo Itaporanga, localizados em uma área de contato entre o sienito alcalifeldspático de Triunfo e as metamórficas do Terreno PiancóAlto Brígida. Estes granitos e granodioritos normalmente são porfiríticos (BRITO NEVES et al., 2003), com foliação magmática, contendo enclaves e pórfiros de microclina com estrutura zonada e seus principais minerais máficos são a biotita e a hornblenda (CPRM, 2000; BRITO NEVES et al., 2003). 


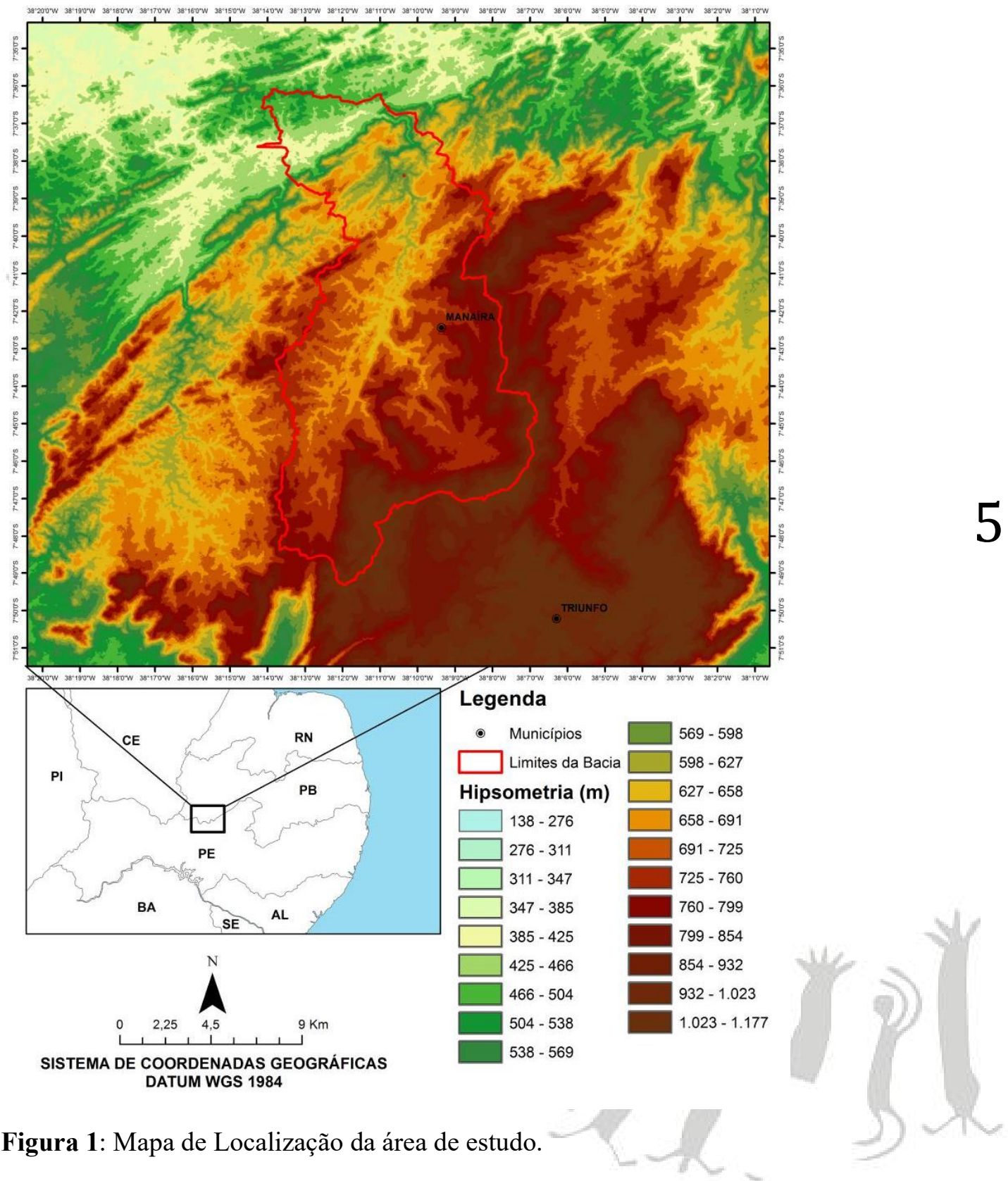

Indexadores: Latindex, ISI, Google Scholar 
Nas porções setentrionais da Bacia do Riacho Grande ocorrem as faixas metamórficas, as encaixantes regionais, compostas de micaxistos, gnaisses e migmatitos referentes aos grupos Salgueiro, Cachoeirinha e Uauá. Fazem parte do embasamento, os sistemas de dobramentos Piancó-Alto Brígida e PajeúParaíba, e foram individualizadas pelo Brito Neves (1975), constituindo os domínios Cearense, Transnordestino e Extremo Nordeste de Schobbenhaus et al (1984).

Os limites acima mencionados são estruturados pelo Terreno Piancó-Alto Brígida. Esse grande domínio é delimitado ao norte pela zona de cisalhamento Patos e ao sul pela zona de cisalhamento Pernambuco (BRITO NEVES et al, 1995). Este terreno é formado por complexos metassedimentares e metavulcanossedimentares com forte presença de granitoides intrusivos do Neoproterozóico (CPRM, 2000; MEDEIROS, 2004). Estes complexos possuem uma orientação geral ENE-WSW em total consonância com os trends regionais. A unidade Complexo Metavulcanossedimentar Riacho Gravatá foi individualizada e referida por Medeiros (2004) como sendo do "final do Mesoproterozóico ao início do Neoproterozóico, tendo sido afetadas pelo evento Cariris Velhos (1 Ga)" (p. 47) (CPRM, 2000; MEDEIROS, 2004) (Figura 2). 


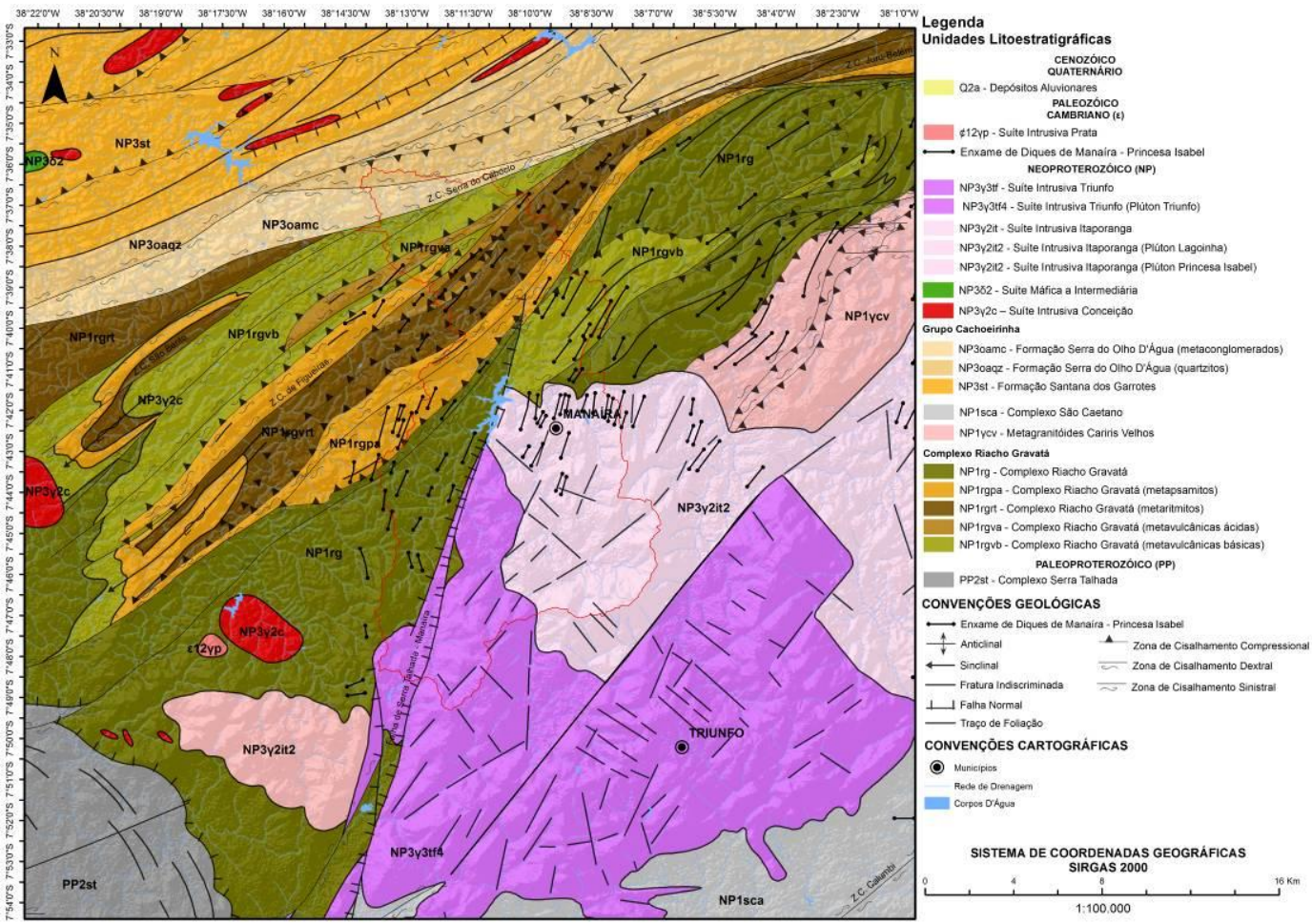

Figura 2: Mapa Geológico da Folha Serra Talhada 1:100.000. Destaque para o corpo plutônico sienítico no setor inferior do mapa e as faixas metamórficas controladas estruturalmente pelas zonas de fraqueza nos setores setentrionais.

O Maciço sienítico da Serra da Baixa Verde se impõe na paisagem como um maciço estrutural, este delimita localmente um dos setores da escarpa ocidental do Planalto da Borborema. As cimeiras do planalto se apresentam bastante dissecadas, formando topos tabulares separados por incisões fluviais em forma de "V", com encostas com alto grau de declividade $\left(20^{\circ}\right.$ a $\left.50^{\circ}\right)$. É notável a remoção 
do manto de intemperismo exibindo desse modo, a rocha fresca; bem como a deposição de materiais coluviais nas médias e baixas encostas.

No contexto regional, a transição do maciço para a depressão sertaneja é distinguida pelo contato entre o sienito e as rochas metamórficas, estas com diferentes graus de metamorfismo que estruturam as faixas de dobramentos circundantes (CORREA, 2001). Adjacente à cimeira do planalto há presença de um setor rebaixado, chamado de Depressão Intraplanáltica de Manaíra, esse setor marca o contato entre o sienito e os granitóides da Suíte Itaporanga. Trata-se de uma superfície em um patamar de 750 metros que apresenta uma sequencia de diques estruturais compostos de sienitos e granodiorito.

No setor ao norte da Depressão de Manaíra, as faixas de dobramento são marcadas na paisagem pela presença de um relevo fortemente dissecado com sequencias de cristas e vales fortemente controlado pelas estruturas presentes na área com as zonas de cisalhamento e falhas de empurrão que comandam a geometria das cristas e dos vales entalhados desses setores setentrionais (TAVARES, 2015) (Figura 3). 


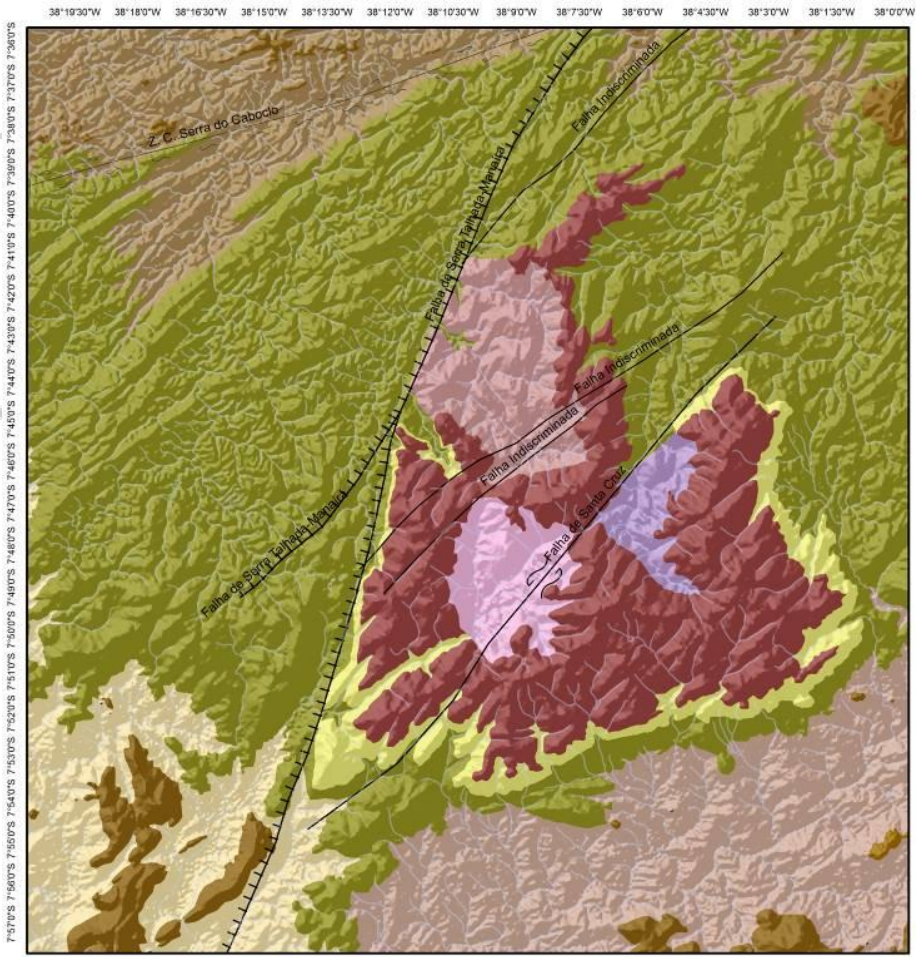

\section{Legenda}

Drenagem

\section{Estruturas}

11 Falha Extensional

- Falha Indiscriminada

$\approx$ Falha Transcorrente Sinistral

Zona de Cisalhamento Transcorrente Dextral

Morfoestruturas

Depressão Intraplanáltica de Sta. Cruz da Baixa Verde

Depressão Intraplanáltica de São José da Princesa

Depressão Intraplanáltica do Pajeủ

Depressão Intraplanáltica do Riacho Grande

Depressão Sertaneja

Encostas do Maciço

Maciço Estrutural

Maciço Estrutural em Forma de Crista

Planalto Sertanejo

Planalto da Borborema Dissecado

Superficie de Cimeira

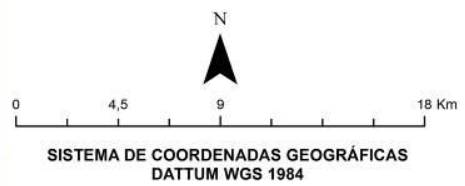

9

Figura 3: Compartimentação Geomorfológica do Maciço da Serra da Baixa Verde. As áreas rebaixadas dentro do contexto do maciço representam as depressões intraplanálticas que se apresentam desconectadas entre si e sob controle direto da estrutura.

\section{MATERIAIS E MÉTODOS}

A análise dos controles da sedimentação na área de pesquisa foi alicerçada nas técnicas de análise morfotectônica do relevo a partir dos seus indicadores e análises morfométricas do relevo e da rede de drenagem. A morfometria foi mensurada com a extração dos lineamentos de relevo e da drenagem, perfil longitudinal do riacho Grande e análise do índice relação Declividade/Extensão 
(RDE). Os dados obtidos em gabinete foram confrontados com visita à campo das áreas que apresentaram estocagem de sedimentos e anomalias que indicam possíveis controles estruturais sobre a geometria das formas.

A análise morfotectônica foi baseada na identificação de anomalias geomorfológicas. Estas feições foram sugeridas primeiramente por Goy et al. (1991) e indicam a ocorrência de atividade neotectônica. Também foram analisadas feições associadas a falhamentos como facetas triangulares $\mathrm{e}$ trapezoidais (WALLACE, 1978), Shutter Ridges (COTTON, 1948), escarpas (STEWART \& HANCOCK, 1990 E 1991), capturas de drenagem (BIANCOTTI, 1979), depósitos superficiais deformados (VERSTAPPEN, 1983), anfiteatros de erosão, cristas, vales assimétricos e vales lineares. Para a identificação das feições morfotectônicas, foram utilizadas imagens de satélite do LANDSAT 8, adquiridas através do site do USGS (Serviço Geológico Norteamericano) e manipuladas através do demonstrativo do software ArcGis10.1 Posteriormente foram identificadas feições morfotectônicas no software ArGis 10.1. Para a identificação das evidências deformacionais recentes foram feitos um empilhamento de bandas 1 a 7 e 8 e a composição utilizada foi a 754 para assim poder visualizar as feições morfotectônicas, como capturas de drenagem, vales retilíneos, facetas triangulares e trapezoidais, cristas, anfiteatros de erosão, que foram identificadas segundo metodologia de Hiruma (1999), Missura (2006) e Tavares et al (2014) e Tavares (2015). 
Os traçados dos lineamentos de relevo foram obtidos a partir da ferramenta HILLSHADE do ArcGis 10.1. O HILLSHADE foi realizado em uma imagem de radar topográfico SRTM (Shuttle Radar Topography Mission) onde é possível dispor ângulos diferentes de incidência da luz solar com relação à topografia. Essa modificação dos ângulos de incidência do Sol sobre a imagem topográfica permite a visualização de lineamentos de relevo sob os ângulos de $45^{\circ}, 90^{\circ}, 315^{\circ}$ e $360^{\circ}$. Com a extração dos lineamentos a partir das Hillshades é possível fazer a relação entre os modelados (com a construção de um Modelo Digital do terreno), sua linearidade e as principais estruturas geológicas que ocorrem na região. Os lineamentos de drenagem foram traçados a partir da extração da hidrografia com os dados SRTM no software ArcGis 10.1, e consequente desenho dos canais que apresentam segmentos retilíneos. Com a extração desses canais foi possível realizar a relação entre a disposição geométrica da drenagem com a litologia, estruturas e geomorfologia.

A proposta de Hack (1973) determina se um rio estaria em equilíbrio geomorfológico ou não a partir de uma relação entre a declividade deste rio e sua extensão. Esta relação foi denominada por Hack (1973) de Stream LenghtGradient Index (SL Index). No Brasil ela é também conhecida como Relação Declividade Extensão (RDE) (ETCHEBEHERE et al, 2006). Este índice é utilizado como um elemento básico e de fácil aplicação na determinação de anomalias nos cursos d'água. A utilização desse índice permite detectar, no perfil longitudinal de um rio, alterações no seu curso, uma vez que relaciona a 
declividade do canal com a extensão do respectivo trecho, fornecendo assim um parâmetro quantitativo para comparação de trechos fluviais de diferentes magnitudes (MARTINEZ, 2005).

A utilização deste índice permite identificar, ao longo do perfil longitudinal de um rio, alterações em seu curso, uma vez que relaciona a declividade do canal fluvial com a extensão do referido trecho. Partindo desta premissa, o índice declividade extensão por trecho é calculado através da seguinte fórmula:

$$
\text { RDEtrecho }=(\Delta H / \Delta L) \cdot L
$$

Onde $\Delta \mathrm{H}$ é a diferença altimétrica entre os dois pontos selecionados do curso d'água; $\Delta \mathrm{L}$ corresponde à extensão do trecho analisado; e $\mathrm{L}$ é a extensão total do canal da nascente até o ponto final para onde o índice RDE está sendo calculado.

Também é possível o cálculo do índice RDE (Formula) de um canal fluvial em sua totalidade. Para isso, considera-se a diferença altimétrica entre a cota superior inferior do canal, ou seja, a diferença altimétrica da cota da cabeceira e da cota da foz do canal (em metros) e o logaritmo natural da extensão total do curso de água.

$$
\text { RDEtotal }=\Delta H / \operatorname{lnL}
$$


No que se refere às anomalias de drenagem propriamente ditas, Seeber e Gornitz (1983) consideram como anômalos os índices de RDEtrecho que divididos pelo índice RDEtotal obtiverem valores acima de 2 (dois).

Tais anomalias dividem-se em duas categorias, ou seja, anomalias de $2^{\mathrm{a}}$ ordem são as que a divisão dos índices obtenha resultados entre os limiares 2(dois) a 10 (dez), e as anomalias de $1^{\mathrm{a}}$ ordem são as que este resultado é igual ou superior a 10 (dez). Esta classificação é traduzida como sendo as anomalias de primeira ordem encontradas em locais muito íngremes, as anomalias de $2^{\mathrm{a}}$ ordem encontradas em locais íngremes e quando o índice calculado é menor que 2 (dois) os trechos são pouco íngremes, configurados como gradiente ideal.

Entende-se como perfil longitudinal de um rio a curva obtida através de dados plotados em gráficos de coordenadas cartesianas onde as coordenadas correspondem à altitude $(\mathrm{H})$ contra a distância da jusante $(\mathrm{L})$ expressa pela equação:

$$
H=f(L)
$$

No qual a tangente expressa o gradiente do canal do trecho estudado (MARTINEZ, 2005). Por meio deste perfil aplicado a um curso fluvial pode-se inferir também o comportamento deste gradiente ao longo do canal fluvial, da cabeceira à foz (CHRISTOFOLETTI, 1980). 
Conforme enfatizado por McKeown et. al. (1988), o perfil longitudinal de um curso fluvial em equilíbrio (graded) apresenta a típica forma côncava; qualquer alteração no perfil leva a corrente a se ajustar na busca de um novo equilíbrio, seja por erosão de seu próprio leito, seja gerando agradação. Tomando esta assertiva como válida, trechos de drenagem fora de equilíbrio podem ser indicativos de atividade tectônica recente (ETCHEBEHERE et. al., 2004).

\section{RESULTADOS E DISCUSSÕES:}

\section{Análise morfométrica e estrutural da bacia do riacho grande}

A partir da análise dos fotolineamentos de relevo e drenagem da bacia do Riacho Grande, foi possível observar a presença de diversos segmentos hectométricos e quilométricos. Essa situação pode ser uma resposta aos componentes estruturais presentes na área como a Falha de Serra Talhada, Zonas de Cisalhamento indiscriminadas, Zona de Cisalhamento Serra do Caboclo (setor setentrional) e falhas de empurrão nas faixas de dobramento.

Os lineamentos de drenagem apresentam uma distribuição bem homogênea, no entanto há uma maior concentração de lineamentos de drenagem vinculados à cabeceiras de drenagem nas áreas onde as principais estruturas que cortam o maciço se localizam. As falhas de Serra Talhada à oeste do maciço e uma zona de cisalhamento transcorrente sinistral que perpassa a área no sentido NE-SW estão em áreas onde há uma concentração de cabeceiras de drenagem de ordem zero, com presença de encostas retilíneas e portanto áreas onde a drenagem ainda não 
pôde dissecar o relevo. Sendo assim, a presença desses lineamentos de drenagem associados à drenagem de ordem zero ou de primeira ordem podem estar sob o controle das falhas de zonas de cisalhamento que ocorrem no maciço, o que pode evidenciar que essas encostas ainda pouco dissecadas indicam uma provável dinâmica de alçamento recente desses setores do maciço. Dessa forma, a presença desses lineamentos podem corroborar a ideia de escarpas jovens, reativadas no Cenozóico superior.

Essa situação pode ser melhor visualizada a partir da análise dos diagramas de rosáceas dos lineamentos de drenagem. Há direcionamentos da drenagem nas direções N-S, NE-SW, NW-SE e E-W, com destaque para comprimentos de lineamentos maiores na direção N-S, NE-SW, NW-SE e E-W. Os lineamentos de comprimento menor, que se concentram na direção NE-SW ou NW-SE, são reflexos de possíveis controles por estruturas ao longo dos principais trends que cortam o maciço, dando origem a pequenas cabeceiras de drenagem que se desenvolvem ao longo das escarpas, a situação dessas cabeceiras foi descrita previamente (Figuras 4 e 5 ).

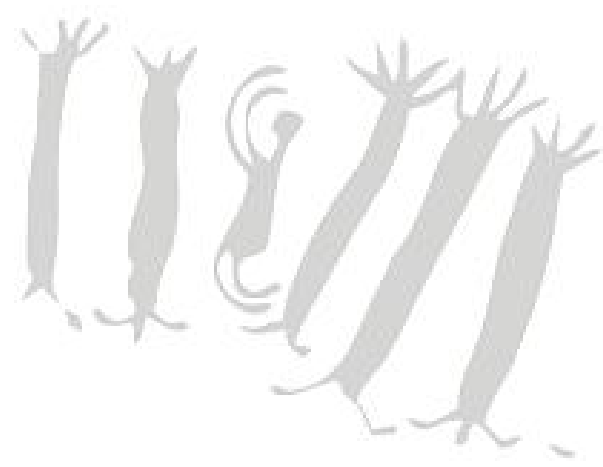




\section{Lineamentos de Relevo}

Frequência Absoluta

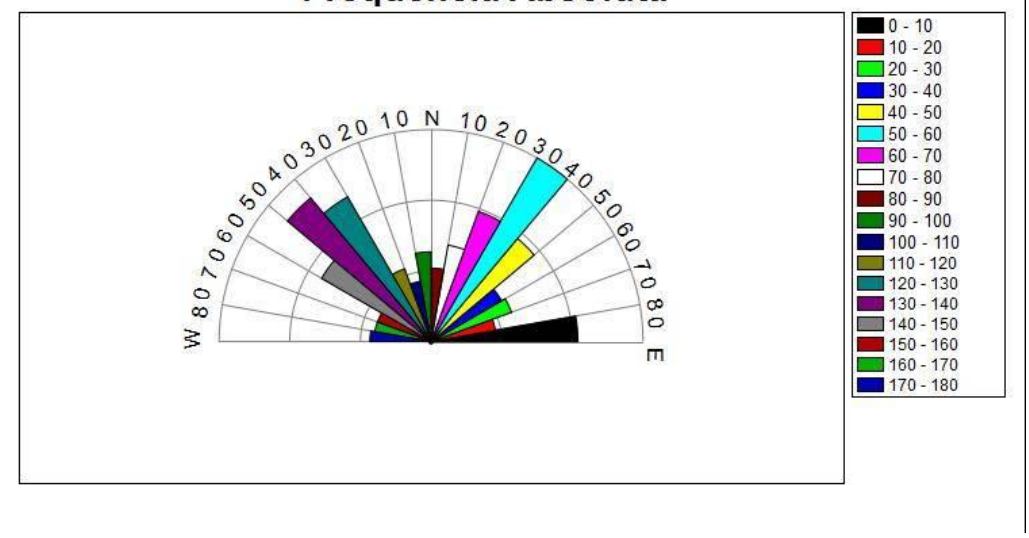

Figura 4: Lineamentos de Relevo com os direcionamentos principais.

No entanto, os lineamentos de drenagem de maior comprimento (direção E-W, NE-SW e NW-SE, estão fortemente associados aos trends regionais que comandam a disposição dos compartimentos de relevo e, consequentemente, dos cursos fluviais. Esses lineamentos de maior comprimento estão vinculados às Zonas de Cisalhamento Pernambuco (lineamentos E-W), Falha de Serra Talhada e Zona de Cisalhamento Serra do Caboclo (lineamentos NE-SW). Esses trends de ordem regional subordinam a drenagem que demanda a Bacia do Pajeú e também as drenagens voltadas para o sistema Piancó-Piranhas-Açu. Esse cenário atesta a ocorrência de uma drenagem adaptada ao condicionamento geotectônico do Planalto da Borborema na sua escarpa ocidental. 


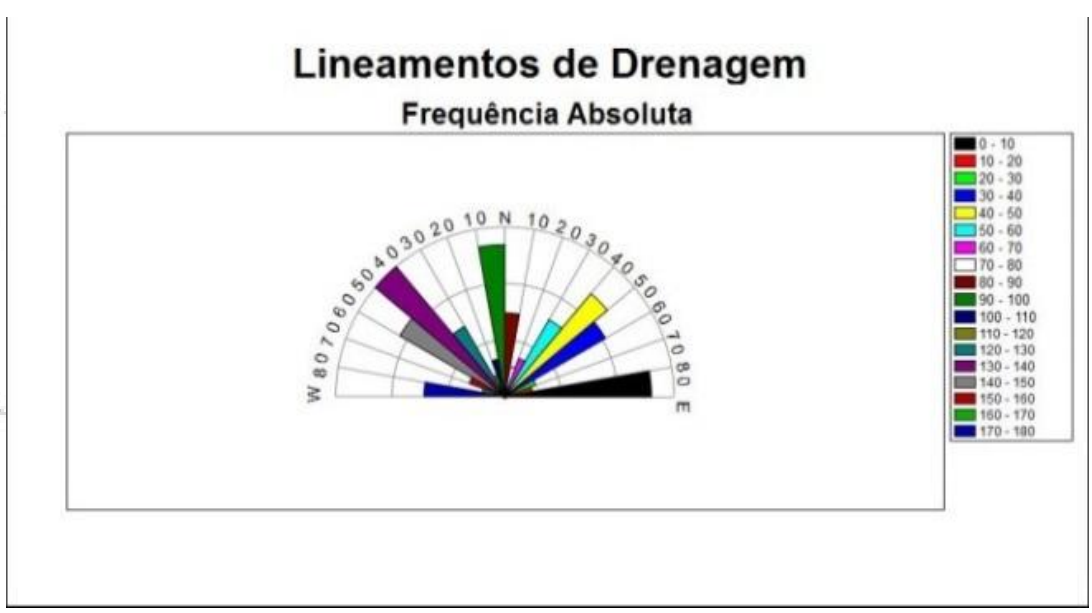

Figura 5: Lineamentos de drenagem obtidos para a área estudada. $\mathrm{O}$ condicionamento dos canais é indicado pela presença de direcionamentos vinculados aos trends regionais E-W e NE-SW.

Análise do Índice de Hack (IH) para cálculo dos índices RDE (relação declividade-extensão) e Perfil Longitudinal do Riacho Grande $\mathrm{O}$ índice de Hack (IH) e os índices RDE permitiram estabelecer os knick-points e áreas de anomalia de RDE no maciço da Serra da Baixa Verde na bacia do Riacho Grande. Foram estabelecidos índices anômalos para o rio principal da bacia estudada.

O riacho Grande faz parte do sistema Piancó-Piranhas-Açu, com suas cabeceiras na superfície de cimeira do maciço da Serra da Baixa Verde. O riacho Grande tem como destaque logo no início do seu curso um segmento linear com uma captura do curso do rio ainda nos setores elevados nas suas nascentes. Essa geometria é controlada por falhas indiscriminadas de direção NE-SW, que partem da Falha de 
Serra Talhada. Essa estrutura além de condicionar a inflexão do canal principal, também é responsável pela presença de anfiteatros suspensos nesse mesmo trecho do rio.

Os anfiteatros estão completamente deslocados com relação ao fundo do vale, indicando assim como nas outras bacias analisadas, uma descida dos níveis de base no contexto geral do maciço. Nesse setor foram identificadas anomalias de segunda ordem indicando quebras de rupturas nas cotas de 860 até 820 metros, mostrando uma coerência com as feições encontradas na área.

O riacho Grande apresenta no seu perfil uma grande ruptura na escarpa setentrional do maciço da Serra da Baixa Verde. Esse trecho demonstra um maior controle estrutural sobre a dinâmica erosiva nessa área, uma vez que o perfil do rio se encontra abaixo da curva de equilíbrio. No entanto, ao atingir as cotas de 750 metros, o rio se encontra numa condição onde os processos sedimentares sobrepõem-se aos processos erosivos. Isso pode ser atestado pela presença de diversas planícies de inundação ao longo do canal principal e seus principais tributários. Essa sedimentação também é controlada pela presença de diques estruturados em granodioritos, estas estruturas barram e confinam os canais fazendo com que a sedimentação entulhe os vales e trunque o sopé das encostas (Figuras 6, 7 e 8, Tabela 1). 
A condição aqui apresentada se assemelha ao contexto ambiental e arqueológico do rio Carnaúba e seus tributários no Seridó Potiguar, onde barramentos e inflexões na drenagem controlam a sedimentação no leito do rio Carnaúba, contribuindo para o acúmulo de material nos baixios, áreas amplamente ocupadas pelos povos Pré-Históricos (MÜTZENBERG et al. 2005; MÜTZENBERG, 2007; BORGES, 2010).
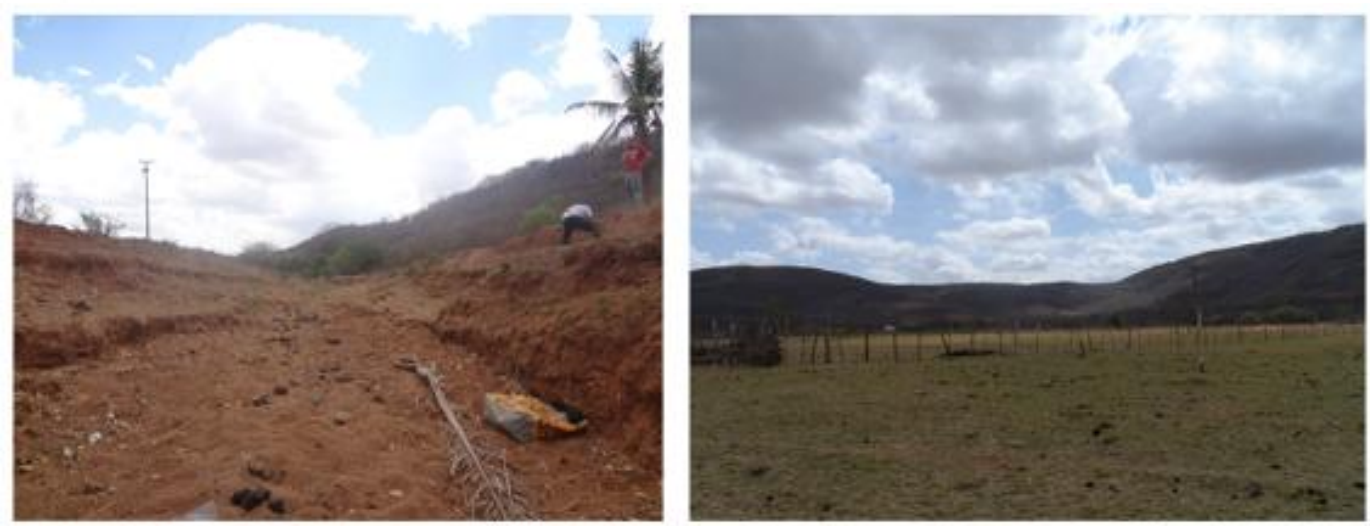

Figura 6: Vales Preenchidos por sedimentos ao longo da Bacia do Riacho Grande.

Perfil Longitudinal - Riacho Grande

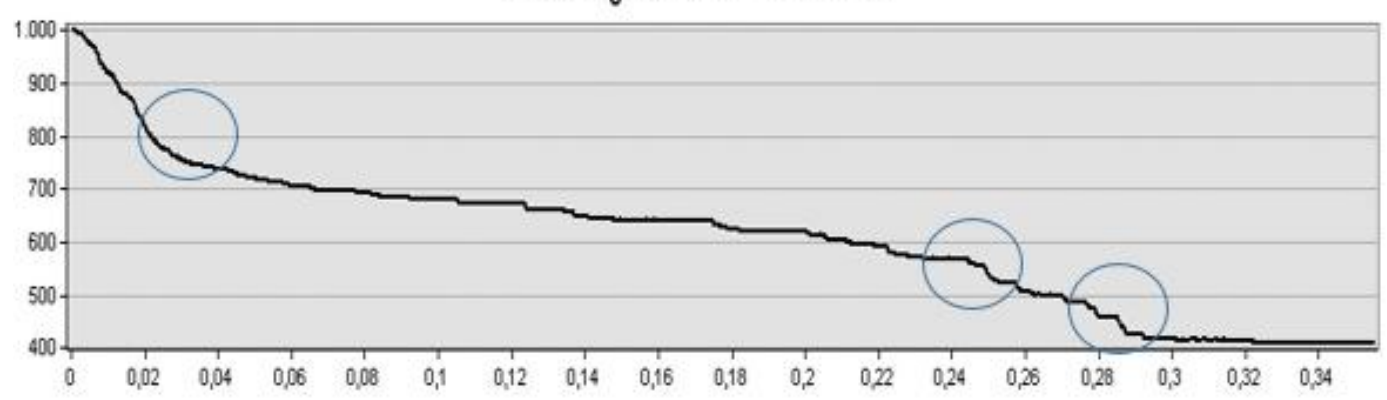

Figura 7: Perfil Longitudinal do riacho Grande. Destaque para a quebra de patamar na cota de 1000 metros, marcando o limite da cimeira do maciço com as escarpas setentrionais do batólito. 
Clio Arqueológica 2017, V32N3, p.1-36, BARROS; CÔRREA; TAVARES

DOI: 10.20891/clio.V32N3p1-36

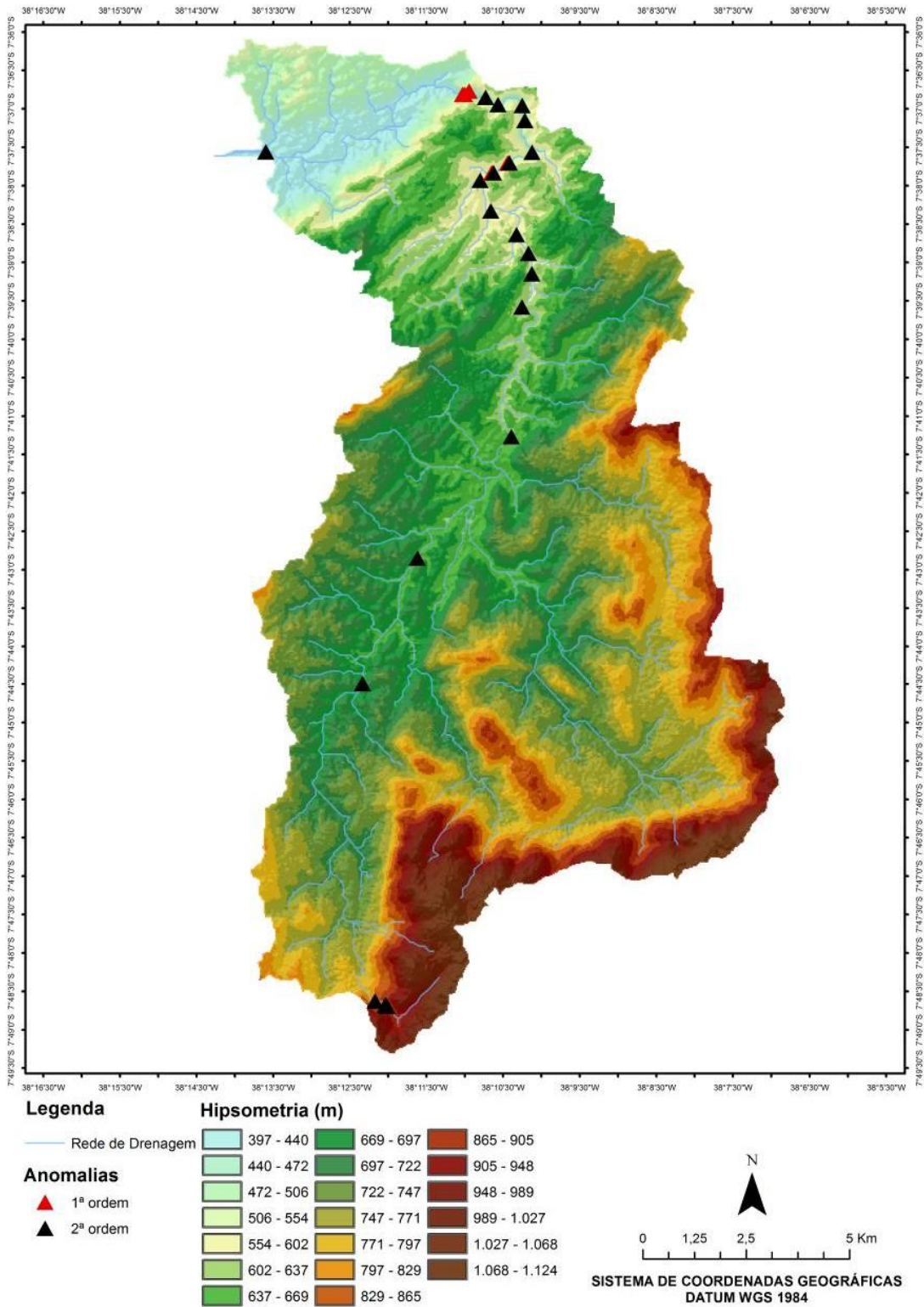

Figura 8: Mapa com indicação das anomalias de drenagem encontradas na bacia. 


\begin{tabular}{|c|c|c|c|c|c|c|c|}
\hline Curva (máxima) & dh & $\begin{array}{c}\text { d (reta entre } \\
\text { curvas) }\end{array}$ & L (trecho) & L (total) & RDE & RDE total & $\begin{array}{c}\text { RDEtrecho/ } \\
\text { RDEtotal }\end{array}$ \\
\hline 860 & 10 & 47 & 47 & 2.011 & 427,8723 & 106,20 & 4,028929759 \\
\hline 850 & 10 & 54 & 54 & 2.065 & 382,4074 & 106,20 & 3,600823045 \\
\hline 820 & 10 & 60 & 60 & 2.348 & 391,3333 & 106,20 & 3,684871312 \\
\hline 680 & 10 & 390 & 398 & 12.610 & 323,3333 & 106,20 & 3,044569994 \\
\hline 660 & 10 & 315 & 346 & 16.426 & 521,4603 & 106,20 & 4,910172481 \\
\hline 640 & 10 & 464 & 544 & 21.351 & 460,1509 & 106,20 & 4,332870641 \\
\hline 610 & 10 & 460 & 478 & 25.389 & 551,9348 & 106,20 & 5,197126013 \\
\hline 600 & 10 & 539 & 634 & 26.023 & 482,8015 & 106,20 & 4,546153335 \\
\hline 590 & 10 & 533 & 573 & 26.596 & 498,9869 & 106,20 & 4,698558068 \\
\hline 580 & 10 & 856 & 945 & 27.541 & 321,7407 & 106,20 & 3,029573015 \\
\hline 570 & 10 & 790 & 1.619 & 29.160 & 369,1139 & 106,20 & 3,475649002 \\
\hline 560 & 10 & 328 & 546 & 29.706 & 905,6707 & 106,20 & 8,527972992 \\
\hline 550 & 10 & 44 & 44 & 29.740 & 6759,091 & 106,20 & 63,64492381 \\
\hline 540 & 10 & 406 & 452 & 30.202 & 743,8916 & 106,20 & 7,004629243 \\
\hline 530 & 10 & 44 & 44 & 30.246 & 6874,091 & 106,20 & 64,72778634 \\
\hline 520 & 10 & 598 & 690 & 30.936 & 517,3244 & 106,20 & 4,871228011 \\
\hline 510 & 10 & 778 & 923 & 31.859 & 409,4987 & 106,20 & 3,8559201 \\
\hline 500 & 10 & 363 & 373 & 32.232 & 887,9339 & 106,20 & 8,360959363 \\
\hline 490 & 10 & 585 & 790 & 33.022 & 564,4786 & 106,20 & 5,31524136 \\
\hline 480 & 10 & 341 & 380 & 33.402 & 979,5308 & 106,20 & 9,223453783 \\
\hline 470 & 10 & 423 & 486 & 33.888 & 801,1348 & 106,20 & 7,54364173 \\
\hline 460 & 10 & 134 & 134 & 34.022 & 2538,955 & 106,20 & 23,90729966 \\
\hline 450 & 10 & 50 & 50 & 34.072 & 6814,4 & 106,20 & 64,16572505 \\
\hline 440 & 10 & 74 & 74 & 34.146 & 4614,324 & 106,20 & 43,44938158 \\
\hline 410 & 10 & 760 & 770 & 41.306 & 543,5 & 106,20 & 5,117702448 \\
\hline
\end{tabular}

Tabela 1: Valores de RDE para o Riacho Grande 
O perfil do riacho Grande apresenta diversas quebras ao atingir os setores estruturados pelos complexos metamórficos de idade mesoproterozóica e pelas estruturas presentes nesses complexos, como a zona de Cisalhamento Juru-Belém (ZCJB), Falhas de Empurrão com caimento para Norte e falhas transcorrentes derivadas da ZCJB. Essas feições estão seguindo os trends regionais do chamado 'Median Shear Corridor' com direcionamento NE-SW. As estruturas presentes na área controlam os compartimentos do relevo, marcados por sucessões de cristas e vales bastante dissecados com pouca ou nenhuma sedimentação nas encostas e fundo do vale.

Essa dissecação é fruto da própria resistência da textura metamórfica frente aos processos intempéricos em clima semiárido. No entanto há também um controle estrutural, uma vez que esse padrão de dissecação forma cristas e vales com direcionamento NE-SW de acordo com o padrão tectônico regional e consequente formação de pequenas cabeceiras de drenagem de ordem zero e de primeira ordem de direção NW-SE, como uma resposta ao direcionamento dos lineamentos principais que se encontram no relevo aguçado e dissecado desse setor nos limites setentrionais do maciço da Serra da Baixa Verde.

É nesse contexto tectônico/estrutural que as principais anomalias foram identificadas. Anomalias de primeira e segunda ordem ficaram concentradas nos patamares de 610 a 440 metros. Esse longo trecho apresenta grande rupturas marcadas por vales em ' $V$ ", rápidos, segmentos lineares, capturas de drenagem 
do rio principal e cachoeiras. Estas últimas responsáveis pelos maiores valores de anomalia.

As anomalias também indicaram descontinuidades litológicas em respostas à própria configuração da geologia local, com sequencias de complexos metamórficos (Riacho Gravatá, Poço dos Cachorros, Serra dos Quintos) com presença de biotita xistos, filitos, monzogranitos milonitizados e augen-gnaisses. Apesar da presença marcante dos contatos litológicos, foi a presença de componentes estruturais que se destacam nesse trecho.

A presença de rochas do substrato com estrias, e estas preenchidas por material supérgeno como (oxi-hiróxidos de $\mathrm{Fe}$ e $\mathrm{Mg}$ ) podem indicar controles estruturais com reativação recente.

A maior anomalia encontrada está em uma zona cisalhante contracional, onde foram observadas estrias preenchidas, veios de quartzo falhados com presença de preenchimento de material supérgeno nas áreas de quebras dos veios, assim como planos de falha indicando deslocamento de blocos. Essa situação implica em reativações dessas antigas zonas de cisalhamento, desencadeando em uma tectônica rúptil em um ambiente de zona dúctil. Dessa forma, os patamares que apresentam anomalias e seus indicadores na área podem trazer luz á dinâmica morfotectônica da área, demonstrando uma contínua reativação dessas zonas de 
cisalhamento Pré-Cambrianas, nos mesmos moldes dos estudos de Gurgel et al (2013), Maia e Bezerra (2014) (Figuras 9 e 10)
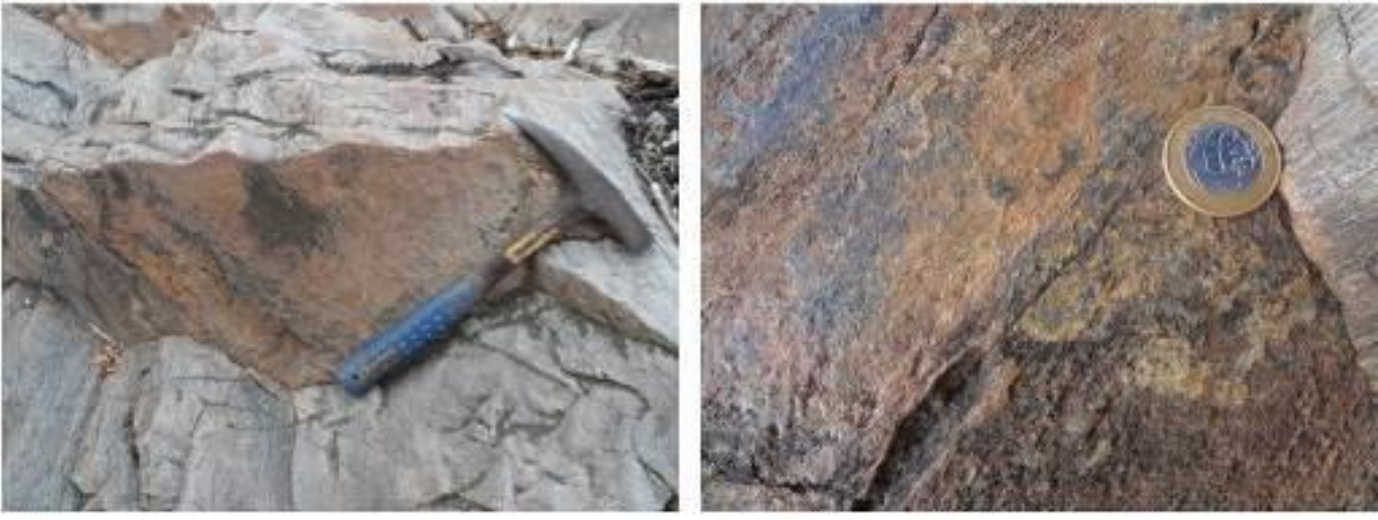

Figura 9: Estrias preenchidas por material supérgeno nos setores de anomalia de primeira ordem do riacho Grande.

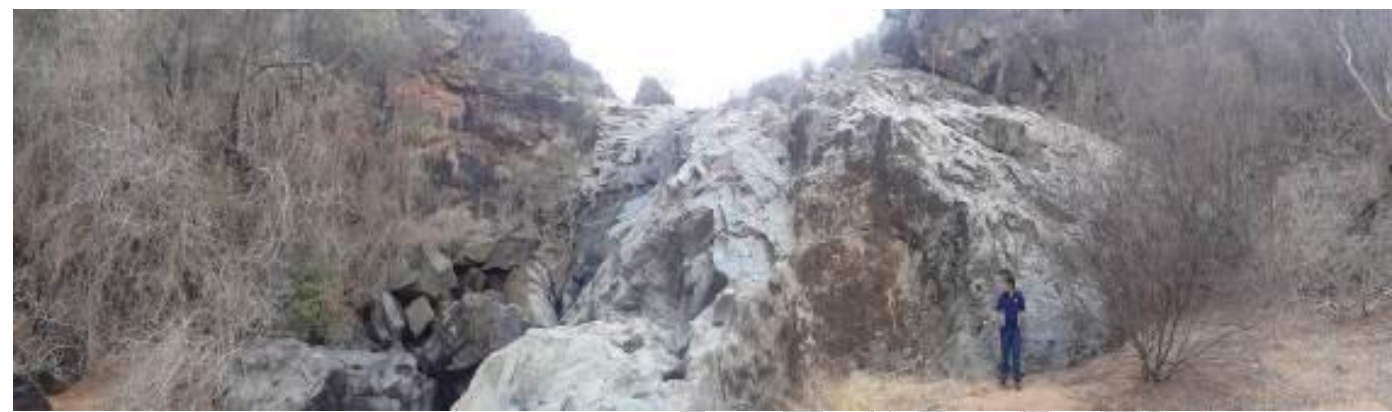

Figura 10: Cachoeira marcando um dos setores de maior anomalia do riacho Grande.

A análise dos perfis longitudinais e das anomalias de RDE dos principais canais que dissecam o maciço demonstrou que há um controle nas quebras dos patamares de cimeiras para as áreas de encostas/escarpas do maciço por parte das estruturas 
presentes no batólito. Isso é observável pela presença dessas rupturas estarem em um posicionamento muito semelhante, com quebras entre 800 metros e nos patamares de 750 metros. Essas rupturas foram identificadas nas escarpas meridional e ocidental do maciço, onde estruturas como a falha de Serra Talhada e zonas de cisalhamento de direção NE-SW se fazem presentes, indicando assim um controle tectônico sobre a quebra desses patamares.

Outra situação a ser destacada é a presença de vales suspensos ao longo de todas as cabeceiras dos principais rios destacados anteriormente, essas feições completamente deslocadas dos níveis contemporâneos da sedimentação sugerem uma dinâmica de soerguimento das cabeceiras, em áreas com presença de zonas de fraqueza estrutural.

A presença apenas de anomalias de segunda ordem no contexto das escarpas do maciço e suas depressões intraplanálticas sugere que o soerguimento da área se deu em todo o contexto do maciço e não de forma pontual, essa situação é verificada in loco a partir dos próprios anfiteatros suspensos encontrados nas escarpas e no interior do maciço. A sedimentação desses anfiteatros e também das encostas e planícies de inundação dos rios é controlada pelas zonas de fraquezas recorrentes no maciço, a partir de barramentos da sedimentação pela presença de colinas estruturadas por falhas e também barramentos do material de fundo do vale em resposta à presença de diques nos setores vinculados às depressões intraplanálticas. 
O RDE trouxe evidências marcantes acerca de uma dinâmica morfotectônica na área do maciço e regiões do entorno, no entanto, mais à frente será discutido os indicadores morfotectônicos encontrados no contexto da bacia do riacho Grande.

\section{Análise dos índices morfotectônicos da bacia do Riacho Grande}

As depressões intraplanálticas ou pedimentos embutidos apresentam feições morfotectônicas relacionadas a dinâmica de rebaixamento do nível de base. Os anfiteatros suspensos se apresentam de forma deslocada do nível de base atual, ocupando por muitas vezes os terços superiores das encostas das depressões. Esse fato atesta que um controle sobre o soerguimento desses vales tem ocorrido na região do maciço, tendo em vista que essa condição ocorre de forma bem distribuída pela área trabalhada. A bacia do riacho Grande é marcada por dois compartimentos maiores, a depressão Intraplanáltica de Manaíra e o Planalto dissecado em faixas metamórficas. Os compartimentos estão dispostos na paisagem de acordo com a estrutura. Os dois setores apresentaram índices que sugerem a atividade tectônica no que concerne a manutenção dos setores elevados, controle na sedimentação de fundo de vale e dinâmica de alçamento de vales suspensos e subida e descida de blocos.

\section{A depressão de Manaíra}

Essa depressão marca o contato do Sienito com os complexos metamórficos das faixas de dobramentos Mesoproterozóicas.-Ainda inseridas no contexto morfoestrutural do Planalto da Borborema, as unidades de encosta da depressão 
intraplanáltica do riacho Grande fazem parte do compartimento de encostas ocidentais do planalto. Estas unidades apresentam forte dissecação com formas aguçadas convexas, estruturadas nos sienitos e granodioritos e nos complexos metamórficos que circundam o maciço da Serra da Baixa Verde. Segundo Correa (2001), esta área está articulada morfoestruturalmente ao planalto como um patamar tectônico que antecede o maciço da Baixa Verde, referido como degrau Manaíra (MONTEIRO, 1988 apud CORREA, 2001). Esse patamar é controlado tectonicamente pela falha de Serra Talhada nos setores das encostas ocidentais e no trecho que limita o domínio do sienito com as faixas de dobramento do Ciclo Cariris Velhos. O limite estrutural nas porções a noroeste da depressão é marcado por um knick-point vinculado à zona da Falha de Serra Talhada (Figuras 11, $12 \mathrm{e}$ $13)$.

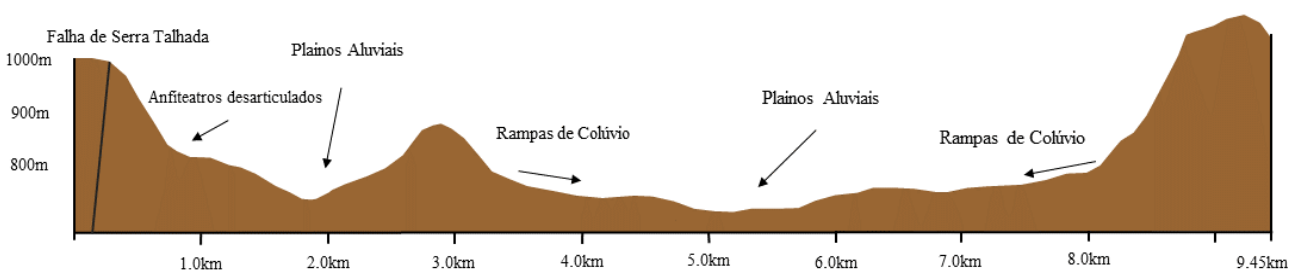

Figura 11: Perfil topográfico da depressão intraplanáltica do riacho Grande.

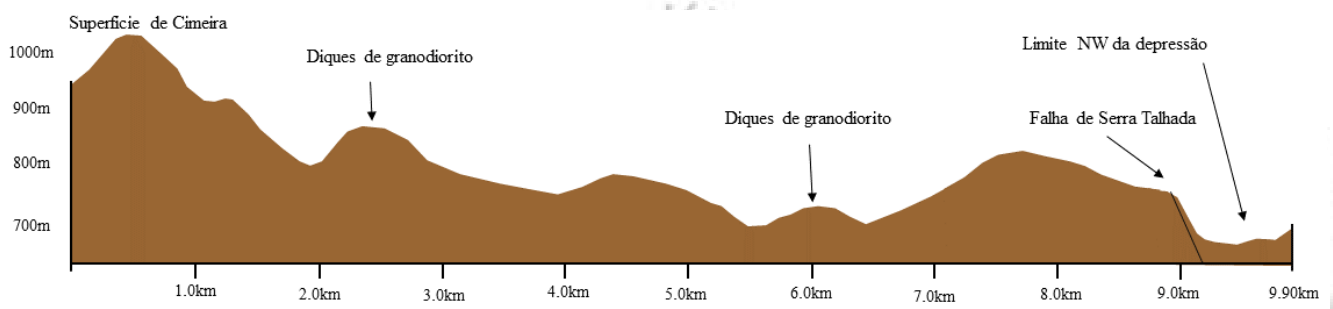

Figura 12: Perfil Topográfico da depressão do riacho Grande com destaque para a quebra de patamar à NW controlado pela Falha de Serra Talhada. 

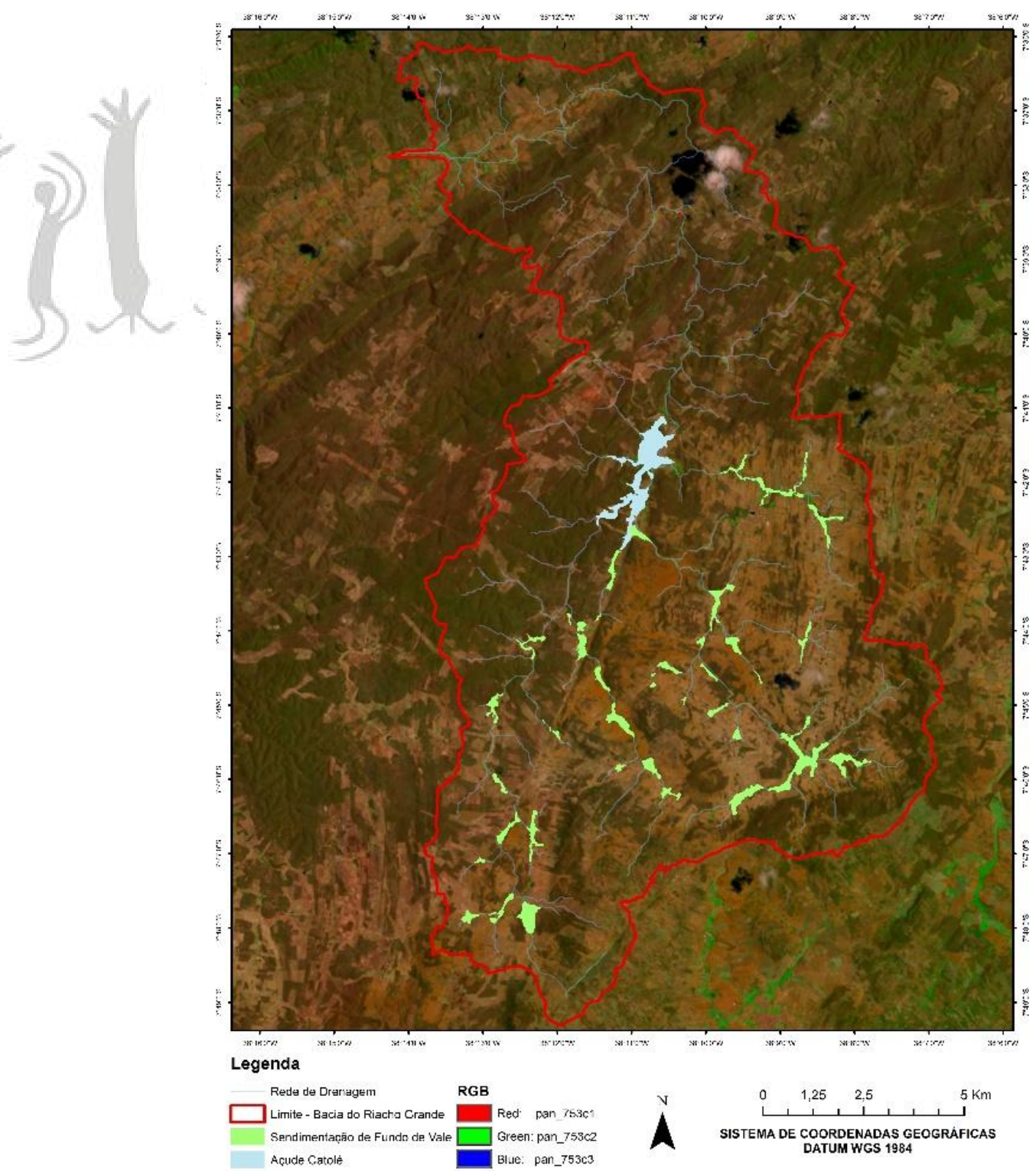

Figura 13: Mapa indicando os principais pontos de sedimentação de fundo de vale. 


\section{Setor Setentrional}

O setor norte da bacia do Riacho Grande é notado pela presença de controles vinculados a diferenças litológicas nas rochas que ocorrem nesse patamar. $\mathrm{O}$ referido setor é notadamente expresso na paisagem de forma bastante dissecada com sequencias de cristas e vales onde a sedimentação está basicamente delimitada no leito do canal principal e dos pequenos tributários do riacho Grande.

Em termos de feições morfotectônicas nessa área é possível observar a ocorrência de cristas e vales lineares sob a orientação da zona de cisalhamento Juru-Belém, falhas de transferência associadas a esta zona de cisalhamento e falhas de empurrão. Esse conjunto estrutural faz desse setor um grande complexo estrutural e litológico, que apresenta quebras de patamares marcados por falhas, estrias em zonas de falha preenchidas por material supérgeno e discordâncias de patamares sob mesmas condições litológicas. Os vales e cristas se orientam na direção NESW, os vales encontrados cortam o relevo na direção NE-SW, dissecando ativamente as cristas e encostas de direção NW-SE. Essas encostas não apresentam material coluvial, o que pode ser uma resposta da tectônica que ao soerguer esses setores não permitiu que o material que outrora jazia nas encostas pudesse permanecer sobre as mesmas.

A ocorrência de quebras de patamares, sob a forma de cachoeiras e quedas d'água, está associada ao cisalhamento Serra do Caboclo e falhas de empurrão desse compartimento. Essas rupturas apresentam estrias preenchidas por material 
supérgeno (óxidos de $\mathrm{Fe}$ e $\mathrm{Mn}$ ) indicando a movimentação de blocos nesse setor. Essas quebras estão associadas a anomalias de drenagem do principal curso fluvial dessa área, o riacho Grande. As anomalias de RDE indicaram sequências anômalas de primeira ordem associadas a um possível controle estrutural sobre a disposição da drenagem.

A complexidade litológica desse compartimento também indica prováveis controles de ordem tectônica. A presença de uma mesma litologia composta de rochas metavulcânicas ácidas em posições topográficas completamente distintas, indicam quebras de patamares nesse setor. A descontinuidade marca um desnível de 300 metros, da área das superfícies dissecadas em rochas metamórficas até a área da Depressão Sertaneja/Planalto Sertanejo. A mesma litologia se encontra em descontinuidade altimétrica de pelo menos 300 metros, e essa descontinuidade é limitada por falhamento associado à zona de cisalhamento Serra do Caboclo.

Essa ruptura é marcada na paisagem como uma região plana à suave ondulada, delimitada por áreas mais elevadas adjacentes, se assemelhando a uma situação tectônica de gráben (Gráben de Santana?) e horst. As duas margens possuem presença de falhas e estrias preenchidas por material supérgeno. A litologia dos possíveis horsts (?) são a biotita clorita dos complexos metamórficos das superfícies dissecadas e os metaconglomerados do Planalto Sertanejo, enquanto que a área rebaixada está demarcada por rochas metavulcânicas ácidas. Outro ponto a se destacar é a assimetria das áreas adjacentes. 


\section{CONSIDERAÇÕES FINAIS}

No contexto regional a drenagem responde às condições estruturais e às formas de relevo de modo que a disposição geométrica dos principais rios está condicionada aos trends estruturais que constituem zonas de fraqueza onde estes se instalaram, como o riacho Grande que, assim como grande parte das drenagens derivadas do Sistema Piancó-Piranhas-Açu, obedece a uma direção preferencial para NE-SW. As cabeceiras do riacho apresentam desarticuladas do fundo de vale, a estrutura presente atua na quebra desse compartimento e consequente mudança de nível de base nesse setor da Bacia. No entanto, nos setores rebaixados próximos as escarpas da Serra da Baixa Verde, a chamada depressão intraplanáltica de Manaíra, a estrutura comanda fortemente a deposição de fundo de vale. Os processos de sedimentação se sobrepõem à erosão, com formação de planícies de inundação ao longo do canal principal e seus principais tributários. Essa sedimentação é controlada pela presença dos diques, que bloqueiam e confinam as drenagens oriundas dos setores de cimeira do maciço. Assim, é possível observar sequencias de planícies de inundação completamente entulhadas de sedimentos, afogando os vales, chegando a truncar os colúvios que ocorrem nas encostas dos diques. Estes seguem uma orientação NNE-SSW e NW-SE, ora em concordância ora em discordância com os principais lineamentos estruturais da área. Nos setores setentrionais da bacia, a geologia encaixante sob a forma de complexos metamórficos estruturam uma sequência de cristas e vales bastante dissecados, sem cobertura coluvial com a concentração dos sedimentos limitada apenas ao leito do rio, podendo indicar que a sedimentação das encostas foi evacuada pela 
forte dissecação e que apenas os vales confinados conseguem acumular sedimentação. Nesses setores, quebras de patamar se fazem presentes ao longo do curso do rio e estão associadas a anomalias de drenagem do principal curso fluvial dessa área, o riacho Grande. As anomalias de RDE indicaram sequências anômalas de primeira ordem associadas a um possível controle estrutural sobre a disposição da drenagem. Assim, na bacia do riacho Grande a estrutura atua fortemente no comando da disposição espacial da sedimentação nos setores próximos as cabeceiras e no confinamento dos vales nos setores setentrionais, indicando uma dinâmica de movimentação de blocos causando rupturas, estas ora controlando o acúmulo de sedimentos sob a forma de vales entulhados, ora a retirada de material das encostas e consequente confinamento dos canais com sedimentação limitada ao leito do rio. Situação que se assemelha com ambientes de ocupação de povos Pré-Históricos, aonde áreas com forte capacidade de retenção de água se tornam favoráveis para o estabelecimento de sítios arqueológicos a céu aberto nesses modelados de acumulação.

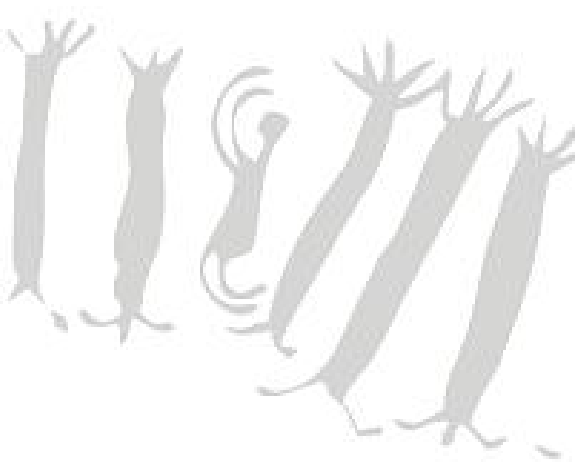




\section{REFERÊNCIAS BIBLIOGRÁFICAS}

BIANCOTTI A. Rapporti fra morfologia e tettonica nella pianura cuneese. Geografia Fisicia e Dinâmica Quaternária, v.2. p.51-56. 1979.

BORGES, F. M. Os sítios arqueológicos Furna do Umbuzeiro e baixa do Umbuzeiro: caracterização de um padrão de assentamento na área arqueológica do Seridó - Carnaúba dos Dantas - RN, Brasil. Tese de Doutorado. Recife: Programa de Pós-Graduação em Arqueologia -UFPE, 235p, 2010.

BRITO NEVES, B.B. América do Sul: quatro fusões, quatro fissões e o processo acrecionário andino. Bahia. VII Simpósio Nacional de Estudos Tectônicos, Anais SBG. 11-13. 1999.

BRITO NEVES, B.B. Regionalização geotectônica do Pré-Cambriano nordestino. Tese de Doutorado, São Paulo: Instituto de Geociências - USP, 198p, 1975.

BRITO NEVES, B.B., SANTOS, E.J., VAN SCHMUS, W.R. Tectonic history of the Borborema Province, northeastern Brazil. In: Cordani, U., Milani, E.J., Thomaz Filho, A., Campos, D.A. (Eds.), Tectonic Evolution of South America, Proceedings of the 31st International Geological Congress, Rio de Janeiro, pp. 151-182, 2000.

BULL, W. B. e WALLACE, R.E. Tectonic geomorphology. Geology. 1986.

BURBANK, D.W. \& ANDERSON, R.S. Tectonic geomorphology. 2.ed., Massachusetts, Blackwell Science. 2011. 274 p.

CHRISTOFOLETTI, A. Geomorfologia. São Paulo: Editora Edgar Blücher. $2^{\circ}$ edição. 188 pg. 1980.

Companhia de Pesquisa de Recursos Minerais - CPRM. 2000./Disponível em $<$ http://geobank.sa.cprm.gov.br/>. Acesso em Setembro de 2010.

CORRÊA, A. C. B. Dinâmica geomorfológica dos compartimentos elevados do Planalto da Borborema, Nordeste do Brasil. Rio Claro, 386p. Tese de Doutorado IGCE, UNESP. 2001. 
CORRÊA, A. C. B.; TAVARES, B. A. C.; MONTEIRO, K. A.; CAVALCANTI, L. C. S.; LIRA, D. R. Megageomorfologia E Morfoestrutura Do Planalto Da Borborema. Revista do Instituto Geológico, São Paulo, 31 (1/2), p.35-52, 2010.

COTTON C. A. Landscape - as developed by the processes of normal erosion. 2 ed. New York: John Wiley \& Sons, 1948. 509 p.

DOORNKAMP, J. C. Geomorphological approaches to the study of neotectonics. Journal of the Geological Society. v.143, p.335-345. 1986.

DRAGUT, L. \& BLASCHKE, T. Automated classification of landform elements using object-based image analysis. Geomorphology. v.81.p.330-344. 2006.

ETCHEBEHERE, M. L.; SAAD, A. R.; FULFARO, V. J.; PERINOTTO, J. A. J. Aplicação do Índice "Relação Declividade-Extensão - RDE" na Bacia do Rio do Peixe (SP) para detecção de deformações Neotectônicas. Revista do Instituto de Geociências USP, v. 4, N. 2, p. 43-56, 2004.

ETCHEBEHERE, M.L.C.; SAAD, A.R.; SANTONI, G.; CASADO, F.C.; FULFARO, V.J. Deteç̧ão de prováveis deformações neotectônicas no vale do rio do Peixe, região ocidental paulista, mediante aplicação de índices RDE (Relação Declividade-Extensão) em segmentos de drenagem. Geociências. São Paulo, 25:271-287. 2006.

GURGEL, S. P. P.; BEZERRA, F. H. R. ; CORRÊA, A. C.B. ; MARQUES, F O. ; MAIA, R. P. . Cenozoic uplift and erosion of structural landforms in NE Brazil. Geomorphology (Amsterdam), v. 186, p. 68, 2013.

HACK, J. Stream-profile analysis and stream-gradient index. Journal of Research of the United Sates Geological Survey, v. 1, n. 4, p. 421-429, 1973.

HIRUMA, S.T. Neotectônica no Planalto de Campos de Jordão, SP. Dissertação (Mestrado em Geologia Sedimentar). Instituto de Geociências - USP. São Paulo. 1999. $102 p$.

MAIA, R. P.; BEZERRA, F. H. R. Inversão neotectônica do relevo na Bacia Potiguar, nordeste do Brasil. Revista Brasileira de Geomorfologia, São Paulo, v.15, n.1, (Jan-Mar) p.61-74, 2014. 


\section{Clio Arqueológica 2017, V32N3, p.1-36, BARROS; CÔRREA; TAVARES \\ DOI: 10.20891/clio.V32N3p1-36}

MARTINEZ, M. Aplicação de parâmetros morfométricos de drenagem na bacia do rio Pirapó: o perfil longitudinal. Dissertação (mestrado). Maringá, 2005.

McKEOWN, F. A.; JONES-CECIL, M.; ASKEW, B. L.; McGRATH, M. B.. Analysis of stream-profile data and inferred tectonic activity, Eastern Ozark Mountains region. U. S. Geological Survey Bulletin, n. 1807, p. 1-39, 1988.

MEDEIROS, V. C. Evolução Geodinâmica e Condicionamento estrutural dos terrenos Piancó-Alto Brígida e Alto Pajeú, Domínio da Zona Transversal, NE do Brasil. Tese de Doutorado: Universidade Federal do Rio Grande do Norte, 2004.

MISSURA, R. Análise morfoestratigráfica da bacia do Ribeirão dos Poncianos-MG. Dissertação de Mestrado. UNESP. Rio Claro. 2006. 136p.

MONTEIRO, K. A. Análise geomorfológica da escarpa oriental da Borborema a partir da aplicação de métodos morfométricos e análises estruturais. 222 f. 2015. Tese (Doutorado em Geografia) - Programa de Pós Graduação em Geografia, Universidade Federal do Pernambuco, Recife, 2015.

MONTEIRO, K. A.; TAVARES, B. A. C.; CORRÊA, A C. B. Aplicação do índice de Hack no rio Ipojuca para identificação de setores anômalos de drenagem e rupturas de relevo. São Paulo, UNESP, Geociências, v. 33, n. 4, p.616-628, 2014.

MUTZENBERG, D. da S. Gênese e ocupação pré-histórica do sítio arqueológico Pedra do Alexandre: uma abordagem a partir da caracterização paleoambiental do vale do rio Carnaúba-RN. Recife, UFPE. 2007.

MUTZENBERG, D. da S; TAVARES, B. de A. C; CORRÊA, A. C. de B. A influência dos controles estruturais sobre a morfogênese e a sedimentação neógena na bacia do rio Carnaúba (RN) e sua aplicação aos estudos geoarqueológicos do Seridó. Clio - Série Arqueológica, UFPE, Recife, PE, n.19, p. 112-125. 2005, v.2.

SCHOBBENHAUS, C. et al. Geologia do Brasil. Rio de Janeiro: DNPM, 1984. 501 p.

SEEBER, L.; GORNITZ, V. River profiles along the Himalayan arc as indicators of active tectonics. Tectonophysics, v. 92, p. 335-467, 1983. 
STEWART I.S. \& HANCOCK P.L. Neotectonics. In: P.L.HANCOCK (ed.), Continental deformation. Oxford: Pergamon,. p.370-409. 1994.

STEWART I.S. \& HANCOCK P.L. What is a fault scarp? Episodes, 13(4): 1990. p.256263.

TAVARES, B. A. C. Evolução morfotectônica dos pedimentos embutidos no planalto da Borborema, Nordeste do Brasil. 2015. 251 f. Tese (Doutorado em Geografia) - Programa de Pós Graduação em Geografia, Universidade Federal do Pernambuco, Recife, 2015.

TAVARES, B. A. C.; CORREA, A . C. B; LIRA, D. R.; CAVAlCANTI, L. C. S. Compartimentação geomorfológica e morfotectônica do gráben do Cariatá, Paraíba, a partir de imageamento remoto. Revista Brasileira de Geomorfologia. v.15, n.4, (Out-Dez) p.523-538, 2014.

VERSTAPPEN, H.T. Applied geomorphology. Amsterdam: Elsevier, 1983. 437p.

WALLACE R.E. Geometry and rates of change of faultgenerated range fronts, NorthCentral Nevada. Journal of Research of the U.S. Geological Survey, 6(5): p.637-650. 1978. 